\title{
1. Understanding the Macassans: A regional approach
}

\author{
Marshall Clark and Sally K. May
}

\section{Introduction}

This volume addresses the history and heritage of the 'Macassan' fishers who made the long and sometimes dangerous maritime journey from the port town of Makassar in southern Sulawesi to the coastline of Arnhem Land and the Kimberley, northern Australia, from before European settlement in Australia until the early twentieth century. ${ }^{1}$ The essays of this collection present an interdisciplinary perspective on the maritime journeys of the Macassans, as well as their encounters with Aboriginal communities in the north and the ongoing impact this exchange has had on Aboriginal languages, societies and cultures. The primary reason for the Macassan visits to the northern Australian waters each year was the collection of trepang (teripang in Indonesian), edible holothurians also known as sea cucumbers, bêche-de-mer or sea slugs. This volume addresses various aspects of the historical development and impact of the trepang trade as well as the enduring encounters between the Macassans and the Indigenous communities of northern Australia. Contemporary heritage iterations and reappropriations are also examined, including heritage listing possibilities, present-day trepang fisheries and Australia-Indonesia bilateral marine cooperation and management.

The history and heritage of the Macassan fishers form an important chapter of Australia's history. They have also played a role in the history of Indonesia and the Southeast Asian region, not to mention East Asia. The Macassan trepang or bêche-de-mer fishery dates back to at least the 1700s, when fishers from the trading port of Makassar and its environs, in the southwestern arm of the island of Sulawesi, made an annual journey to the coasts of the Kimberley and Arnhem Land, known as Kayu Jawa and Marege' respectively. It is quite possible that other voyagers from elsewhere in Indonesia, such as the Bajo (Bajau), also known as the Sama Bajau or Bajau Laut, may have visited Australia even earlier (see Fox 1977). Although the later Macassan crews may have included Sama Bajau and indeed fishers from a variety of ethnic groups such as the Butonese,

1 We would like to thank various colleagues for reading and commenting on an earlier version of this chapter, which has been greatly improved as a result. This includes Campbell Macknight, Kate Lloyd, Ian McIntosh and Paul Taçon. We take full responsibility for any remaining errors or shortcomings. 
the majority of the crew and their vessels were from Makassar and spoke languages used by the main ethnic groups based there - namely, the Bugis and the Makassarese. In large and regular fleets of wooden sailing vessels, known as prau (also spelled in Indonesian and the lingua franca of the region, Malay, as 'perahu'), the Macassans sailed to Australia with the northwest monsoon each December and returned to their home port of Makassar with the southeast trade winds around March or April each year (Macknight 1976; Chaloupka 1993). The trepang catch and trade goods such as pearl shell, beeswax and ironwood were brought back to Makassar and sold to Chinese traders supplying the market of southern China, where trepang were highly sought (Macknight 1976; Clarke 2000). During their visits, the Macassans developed social and economic ties with local Indigenous groups, though the extent of these relationships is still being debated (Macknight 1976; Chaloupka 1996; Clarke and Frederick 2006; Mitchell 1994).

In general, for the Indigenous people of Arnhem Land and the Kimberley, the Macassans were among the first foreigners they had ever come across, provoking a great deal of interest in the various material cultures they subsequently introduced. These items include canoes, sails, hooks, fishing lines, beads and metals, to name just a few. The broader socio-cultural impact of this will be discussed in much greater detail in this volume. Besides introducing various items of material culture, the Macassans employed Indigenous people to help gather and process the trepang catch. Dozens, if not hundreds, of Aboriginal sojourners are said to have sailed on the return voyage to Makassar, settling there and beginning families with local women. Activity in the Macassan trepang industry declined from 1880 onwards due to the taxes and charges being imposed on the visiting trepangers. The last Macassan voyage to Australia took place during the 1906-07 season (see Macknight, this volume), before the South Australian Government effectively refused to grant fishing licences to non-Australian operators (Macknight 1976).

The timing of the earliest Asian visits remains an important and controversial debate in the archaeology and history of northern Australia. There are a number of contrasting views relating to the chronology based on documentary and/or archaeological evidence. As mentioned in his chapter (this volume), Macknight (1976, p. 97; 1986, p. 69) initially placed the origins of the Macassan trepang industry between 1650 and 1750 AD. He later revised his evaluation, arguing the industry was not in full swing until the 1780s, with some possible earlier excursions to northern Australia occurring from the 1750s. Macknight's initial evaluation was based on a number of written sources that date the industry to the eighteenth century, including historical accounts, personal journals and government records, while his re-evaluation (Macknight 2008) is based on evidence presented by Knapp and Sutherland's (2004) study of detailed trade 
data for Makassar. At the same time, a number of archaeologists have questioned Macknight's document-based theory and point to his own archaeological work as evidence for earlier visits. Radiocarbon dates on wood charcoal found in the remains of trepang boiling fireplaces returned dates several hundred years older than ages inferred from documentary evidence. These three geographically separate sites (at Anuru Bay, Entrance Island and Groote Eylandt) returned radiocarbon dates with ages ranging from 1170 to 1520 AD (Macknight 1976, pp. 98-9). Due to the discrepancy between these dates and historical accounts, Macknight argued that there must be a source of error in the archaeological dates. Indeed, Mitchell (1994) argued that the radiocarbon dates were unreliable and that they result from technical problems with radiocarbon analysis of mangrove wood.

In addition to the work of Macknight, a pottery shard at Dadirringka rock shelter on Groote Eylandt was found below where a calibrated radiocarbon date of between 904 and 731 BP was obtained (Clarke and Frederick 2011, p. 151). Clarke $(1994,2000)$ argues that she found further evidence to support earlier contact from an analysis of material excavated at Malmudinga. Importantly, however, Clarke maintains that 'this initial contact was not necessarily of the order of magnitude of the later trepang industry, organised from the city of Macassar and may have been both sporadic and small scale' (Clarke 1994, p. 470).

Recent rock art and archaeological work undertaken in northwestern Arnhem Land has contributed to the ongoing debate. This includes the radiocarbon dating of a beeswax figure overlaying a painting of a Southeast Asian sailing vessel in the Wellington Range (Taçon et al. 2010; see also Taçon and May, this volume). Results indicate this sailing vessel, most probably a prau, was painted prior to $1664 \mathrm{AD}$, and there is a 99.7 per cent probability that the overlying beeswax figure was made between 1517 and 1664 AD. Recent archaeological excavations and re-evaluation of earlier excavated materials at the Anuru Bay site have also provided insights into the timing of Macassan visits (Theden-Ringl et al. 2011). The team analysed two skeletons excavated by Macknight in the 1960s and confirmed Macknight's argument that the skeletons were of Southeast Asian origin (Theden-Ringl et al. 2011, p. 41). They also suggest that one of the individuals died before 1730 AD (Theden-Ringl et al. 2011, p. 45). Overall, we are entering an exciting new era of archaeological research into Macassan sites and new findings will almost certainly rewrite our understanding of the timing and the nature of early Asian contact with Australia. 


\section{Yalangbara and Trepang}

What has become one of the most celebrated chapters in Australia's history continues to attract great interest. For instance, in the Australian spring of 2011 there were two museum exhibitions highlighting the historical impact of the encounters between the Indigenous people of Arnhem Land and the 'Macassans' of Sulawesi. The first exhibition of the two, Yalangbara: Art of the Djang'kawu, was held at the National Museum of Australia in Canberra. Yalangbara showcases artworks by the Marika family from northeast Arnhem Land, depicting the journey of the Djang'kawu ancestors. The Djang'kawu are believed to be the 'first ancestors' of northeast Arnhem Land, the first people who were born or created there. The paintings illustrate the events associated with the Wanggarr, the 'ancestral dimension' or creative period when the Djang'kuwu undertook their journeys (Morphy 2008). The members of the Marika family are highly regarded as prolific artists, influential teachers, cultural ambassadors, environmentalists and activists. Mawalan 1 Marika, for example, was a key guide and informant for Campbell Macknight, who travelled to the region in the 1960s in preparation for his groundbreaking doctoral research on the history of the Macassan trepang fishers, or trepangers. This research has since been published in the classic book in the field, The Voyage to Marege': Macassan trepangers in northern Australia (Macknight 1976).

The Yalangbara exhibition focuses on the Marika family's most significant clan estate at Yalangbara, or Port Bradshaw, south of Yirrkala in northeast Arnhem Land. Yalangbara, distinguished by its great sand dunes and pristine beaches, is a focal point for ancestral activity. It is the site where the first ancestors, the Djang'kuwu, landed: 'people as far away as western Arnhem Land and south down to Lumbulwar refer to Yalangbara as the place of the first people, the first people who were born or created there' (Marika 2008, p. 8). The Yalangbara collection consists of works produced at the Yirrkala mission in the 1930s as well as rare crayon drawings commissioned by the anthropologist Ronald Berndt, who worked closely with Mawalan 1 Marika and Wandjuk Marika at Yirrkala in 1946-47. Other works include bark paintings from the 1950s and a series of contemporary prints, fibre items, barks and carvings. In terms of themes, the exhibition explores issues such as heritage and land rights as well as the interrelationship between people, their art and the land. For those interested in the centuries-long Macassan-Aboriginal encounter, the Yalangbara works are notable for a recurring element: motifs depicting the legendary 'Bayini', widely believed to be a mythical group of white or golden-coloured Asian seafarers who voyaged to Arnhem Land, before the arrival of the Macassan fishing fleets.

Who are the Bayini? Some scholars such as Macknight have argued that Indigenous Australian ancestral memories of the Bayini or pre-Macassans 
originate from Indigenous Australian visits to the homeland of the Macassans, the port of Makassar (Macknight 2008). Alternatively, Fox (1977) has suggested that the scattered fishers known as the Bajo (Bajau) or Bajau Laut ('Sea Gypsies') were the first fishers and trepangers from Indonesian waters to voyage to northern Australia. Could the Bajo (Bajau) and the Bayini be the one and the same? McIntosh (1995) has argued that the identity of the pre-Macassans as a historical phenomenon has always been something of a conundrum, and will continue to be the case, despite the Bayini occupying centre stage in Yolngu cosmology. McIntosh (2011) has argued that until very recently-1988 to be precise - the Yolngu deliberately concealed the true identity of the Bayini. In the stories that have been disclosed, it appears that, in McIntosh's words, 'the Bayini are seafarers who, at the dawn of time, make their way from points south of Numbulwar in the Gulf of Carpentaria, around Dholtji and Cape Wilberforce, and into Arnhem Bay and Gurrumurru, where their journey ends as mysteriously as it began' (McIntosh 2011, p. 352). In any case, the Bayini iconography of the Yalangbara collection foreshadows another recurring narrative element in their artwork: the ubiquitous presence of the Macassan trepangers in the region, with their distinctive praus, and their hearths, pots, pans and other cooking utensils for boiling, smoking and drying trepang.

In the Yalangbara collection it could be argued that each painting tells a story. Most of the works are a variation on the same theme - that is, the origins of the Djang'kawu ancestors. One of the paintings, Map of Yalangbara (1947), a crayon on paper work by Mawalan Marika, is worth describing in some detail. It is a magnificent topographical work, tracking the intersecting journeys of the Djang'kawu and other travellers in the region, including the Bayini, the adventurer and trepanger Fred Gray, and Macassan trepangers. The painting takes the form of a map of Port Bradshaw. Yellow tracking with a red outline depicts the journeys of the Djang'kawu and the mythical Bayini. A red track with blue outline depicts the route of the Macassan trepangers. The latter track traces their maritime route into Port Bradshaw as it leads to a vegetated granite island in the middle of Lalawuy Bay, Wapilina, which was used as a base and campsite for processing the trepang catch. The footprints of the Djang'kawu intermingling with the trepang in the hearth ashes of the trepangers' camp symbolically reflect the close interaction between the Aboriginal ancestors of the region and the Macassans. The island itself has provided much archaeological evidence for the activities of the Macassans.

The second exhibition of spring 2011 relating to the history and heritage of the Macassans was held at Melbourne Museum. The title of this exhibition was Trepang: China \& the story of Macassan-Aboriginal trade. The exhibition combines historical artefacts, paintings, maps and photographs with new works of art by classically trained Chinese artist Zhou Xiaoping and highly respected artist John 
Bulunbulun. According to the exhibition notes, the aim of the exhibition is to explore the long history of cultural exchange and trade between the Chinese, the Macassan trepangers and northern Australian Aboriginal people. Compared with the Yalangbara exhibition, Trepang places a greater emphasis on the role of China in the Macassan-Aboriginal encounter. This should not be surprising given that Rio Tinto, a large Australian mining company with a long history of commercial ties with China, was a major sponsor of the exhibition. But as this volume of essays will reveal, the role of China in the history and heritage of the Macassans should not be understated. It was the eighteenth-century boom in China that drew in products from Southeast Asia, including the trepang from northern Australia. Thus despite, or even because of, its China-centric focus, the Trepang exhibition is a welcome addition to the overall Macassan narrative. It certainly helps make the trepang industry less 'unknown'. As one visitor to the exhibition's web site remarked, somewhat optimistically, 'maybe the time will come again where cucumbers of the sea become the new food'.

This collection of essays aims to re-examine not only the history and heritage of the Macassans, but also the broader history of the trepang fishery and trade in the region. In one sense, 'the region' can be taken to mean the coastline of northern Australia. In a broader sense, it can also mean Southeast Asia, given that the Macassan trepangers played an important role in the history of colonial Makassar and therefore the development of what has become the Indonesian nation-state(Sutherland 2000). To this day a number of the leading political leaders in the region, including Indonesia's former president B. J. Habibie, Indonesia's former vice-president Yusuf Kalla and the current Malaysian Prime Minister, Najib Razak, trace their ancestry directly back to southern Sulawesi. Beyond this, the Macassan trepang foodway extended to southern China. These days, a good proportion of Indonesia's contemporary trepang industry continues to be centred in present-day Makassar. The islanders of the Spermonde Archipelago offshore from Makassar, for instance, continue to process and supply trepang for the Chinese market. The same can be said for the contemporary trepang fishery in northern Australia, which boasts a modest trade with the Chinese restaurants of Melbourne and Sydney and a multimillion-dollar trade with China itself. It is for these reasons that this collection of essays - combining the expertise of scholars working in the fields of Aboriginal studies, Indonesian studies, archaeology, history, anthropology, human geography, marine resource management, and art and material cultures - literally examines Macassan history and heritage from both sides of the Arafura and Timor seas. 


\section{Trepang in Australia's 'Top End': Contemporary issues}

Before outlining the content of each chapter and the underlying themes of this volume, it is perhaps worth addressing in more detail the status of the contemporary trepang fishery, particularly in the maritime border zone between Indonesia and Australia, which includes the many reefs and islands in the Timor Sea. Of course, we cannot avoid the fact that in present-day Australia the once close trading ties between the trepang fishers of eastern Indonesia and the Indigenous communities of Arnhem Land and the Kimberley have well and truly ceased. There are various reasons for this. On the one hand, the Indigenous communities of northern Australia are now Australian citizens subject to Australian federal and State and Territory laws and, on the other, the trepang fishers of Sulawesi and elsewhere are now Indonesian citizens and thus subject to strictly enforced laws relating to fishing in Australia's northern waters. The politics of refugees, asylum-seekers and people smugglers operating in Australia's northern maritime border zone have ensured that while vessels from the Indonesian archipelago throughout the eighteenth and nineteenth centuries were positively welcomed as a general ragbag source of the unusual, in the contemporary era vessels arriving from the north are generally regarded with suspicion.

In practical terms, if perchance fishers from Sulawesi, or any other part of eastern Indonesia for that matter, were to seek to reclaim their centuries-old tradition of trepang fishing in Australian waters they would be, and quite often are, apprehended, imprisoned and sentenced as 'illegal fishermen' or 'poachers'. This has been the general pattern over the past decade in particular (Fox and Sen 2002; Francis 2006; Ganter 2006). ${ }^{2}$ Why such a harsh stance? In a practical sense, the trepang fishery in Australia, which is still a small-scale operation, cannot absorb the costs associated with poaching. Australia's primary trepang licence holder, Tasmanian Seafoods, has heavily invested in the 'Top End' trepang fishery, which is subject to strict government regulations. Tasmanian Seafoods is also under constant pressure to demonstrate the sustainability of the trepang fishery. Poaching, therefore, is extremely damaging. According to a Tasmanian Seafoods manager: 'We only catch up to 100 tonnes of wet catch each year [in Western Australia] and it wouldn't take much to knock this on its head. There are reefs further afield where illegal poaching has over-fished some areas for trepang and they are closed to commercial wild catch' (Francis 2006).

2 An exception to this is the provision for 'traditional' Indonesian fishers to fish using 'traditional' vessels and fishing techniques in the Australian Fishing Zone (AFZ). This zone is also known as the MoU Box, which was established after a memorandum of understanding (MoU) was signed between the Australian and Indonesian governments in 1974 (see Adhuri, this volume). 
Besides experiencing detainment and, ultimately, deportation, illegal vessels, including fishing gear and catch, are also systematically confiscated by Australian authorities (Fox and Sen 2002; Stacey 2007). Since the 2007 election of the Labor government and the demise of the former conservative government's so-called 'Pacific solution' (offshore detention of asylum-seekers in Pacific Island states), the resurgence in the number of Indonesian vessels transporting asylum-seekers and refugees to Australian shores has added to the sensitive nature of this issue. This has been exacerbated by the failure of the current Labor government's socalled 'Malaysia solution' to its asylum-seeker problem (a bilateral agreement to return asylum-seekers arriving by boat to Malaysia in exchange for already processed refugees). Subsequently, the problem of asylum-seeker boat arrivals has become a serious political one for the Labor government and, for many, the fine line between 'illegal fishermen' and 'people smugglers' along northern Australia's porous border zone has been blurred. In the eyes of naval, fisheries and customs personnel actually dealing with both parties, however, the distinction is still quite clear.

In any case, trepang still attracts stray Indonesian fishing vessels to Australian shores, despite the great costs associated with detection and apprehension. But what is trepang and how is this ongoing attraction best explained? Trepang belongs to the phylum Echinodermata, class Holothuroidea, of which some 900 species have been identified. As noted earlier, the term trepang is also widely interchangeable with bêche-de-mer. While the Indonesian term teripang certainly refers to the live animal in Indonesian, both trepang and bêche-demer can refer to the processed body-wall of sea cucumbers, which are dried, boiled or smoked. In non-technical terms, sea cucumbers are soft-bodied marine animals with a leathery skin and an elongated body and they inhabit the sea floor of all seas, at all depths. Historically, trepang has had a distinct commercial niche in the commodity market of Southeast and East Asia, particularly as it has been used in Chinese traditional cooking since the seventeenth century as a delicacy and as a male sexual-enhancement product. Trepang is also used as a dietary supplement throughout Asia for treating a range of ailments, including ulcers, skin lesions, high blood pressure and quite a few more besides. According to one Chinese source, the medical function of trepang 'is to invigorate the kidney, to benefit the essence of life, to strengthen the penis of man and to treat fistula' (see Macknight, this volume). Besides the ailments already listed, in the northern and eastern coastal states of Peninsular Malaysia ethnic Malays often use trepang, which is known as gamat or gamat emas, as a traditional ointment for skin conditions. In present-day Kuala Lumpur it is also possible to purchase over-the-counter bottles of cough mixture containing traces of trepang.

Chinese traders have long been alert to the 'cure-all' and aphrodisiac qualities of trepang and, as mentioned earlier, it was the demand from China that 
spurred on the Macassan fleets to the shores of northern Australia. Even after the Macassan fishing fleets made their last annual journey to Arnhem Land in 1907, Indonesian trepangers continued to fish in Australian waters, in the Timor Sea in particular, for decades afterwards, illegally. There was a period during the Japanese occupation of East Asia during World War II when the trade ceased altogether (Fox and Sen 2002). But low-level trepang gathering began again in the offshore islands and reefs in the Timor Sea, continuing until very recently, when the Australian Government, under the conservative leadership of prime minister John Howard in particular (1996-2007), demonstrated its determination to clamp down on illegal fishing for trepang and other marine products. The establishment of a Darwin office of the Australian Fisheries Management Authority (AFMA), with the associated hiring of 20 additional compliance officers, was a significant gesture in this regard (AFMA 2006). AFMA's foreign compliance budget was significantly boosted, from \$10 million to \$33 million between 2004-05 and 2006-07 (AFMA 2007). AFMA's increased funding, coupled with a marked increase in the support AFMA received from the Australian Defence Force (ADF) and Customs, had an immediate impact. In 2005-06 at least 368 vessels were detained, which was the peak amount over the past decade (AFMA 2007). Between July 2007 and July 2008, 186 boats were apprehended, of which 141 were Indonesian owned (Howlett 2011). The crews were arrested and transferred to immigration detention centres, and their boats towed to the nearest port, most often Darwin, and burnt. Between July 2008 and December 2011, just 71 vessels in total were destroyed (Howlett 2011), and between July 2010 and April 2011 only 11 foreign boats were caught fishing illegally in northern Australia (Gibson and Razak 2011).

In Australia's northern waters, trepang still appear in relatively abundant numbers, especially in areas where naturally occurring stock have been boosted by ranching. But like the Australian fishing industry in general, the Top End trepang fishery is chronically under-utilised. There are numerous reasons for this, many of them inter-related. Key factors for under-fishing include strict quotas and a business decision by the sole trepang-fishing operator to focus on trepang ranching rather than open-sea harvesting. To some extent the sole licensee is also a victim of the key problems affecting the entire Australian fishing industry - namely, a shortage of experienced fishing and deck crew and, with declining numbers of vessels in operation each year, diminishing fleet capacity (Commonwealth Fisheries Association 2012; Lloyd 2012; Cleary 2010). In response to this, over the past decade the Commonwealth Fisheries Association and various fishing operators have held talks with the Australian Department of Immigration and Citizenship (DIAC) about bringing in foreign workers under the 457 Visa, which is targeted specifically for temporary foreign workers. Moves to outsource fishing quotas to subcontracted foreign fishing fleets are also afoot, as demonstrated by the decision to allow the Dutch-owned 
trawler the FV Margaris to operate out of Devonport, Tasmania, with a licence to catch red bait and mackerel; however, due to public pressure, the Australian Government rescinded this permission and by all accounts changes in legislation will be needed for this sort of thing to occur in the future (Cleary 2010). In the meantime, the demand from China is insatiable and the rest of the world, including Australia and many other nations of the Asia-Pacific, is scrambling to keep up.

\section{The chapters of this volume}

Although a great deal of knowledge has emerged on the history of various trepang fisheries throughout the world, this is the first edited collection of essays on the Australian contribution to the trepang trade, which we believe should not be viewed in isolation from trepang production, trade and consumption elsewhere in the region. The chapters of this volume were first presented at a two-day research symposium hosted by the Institute for Professional Practice in Heritage and the Arts (IPPHA) at The Australian National University, Canberra, in early February 2012. The symposium and this subsequent publication were supported financially by The Australian National University's College of Arts and Social Sciences.

This book, like the symposium that gave birth to it, primarily revolves around a most unassuming creature: the sea cucumber. For centuries, the humble holothurian has emerged as an endless source of curiosity, fascination and trade, arousing a great deal of transnational interaction. Reflecting this, the first few chapters of this volume approach the question of trepang, and Australia's early trepang industry in particular, from a broad regional perspective. We begin with a 'state of the field' chapter by the doyen of Australian 'Macassan' trepang industry research, Campbell Macknight. This chapter aims to collate the various bodies of knowledge devoted to the trepang industry of Australia. It soon becomes apparent that because of the significance of Australia's trepang industry in terms of size, duration and consequence, a great deal of research has emerged. This includes the scattered references to trepang in a series of literatures from China, the Dutch East Indies and colonial Australia, the last of which is largely written in an ethnographic vein. Tindale's study in the 1920s of the effects of contact between the trepangers and local Aborigines is a good example of this genre. In Macknight's words, 'he recorded what he saw and what his informants told him, giving this information an internally consistent form and structure, but not testing it against other sources or approaches'. The ethnographic approach ruled supreme over the next 50 years, with numerous fieldworkers and historians recording a wealth of information about the effects of first contact. Significantly, the informants were all Aboriginal and the focus 
of interest was on Aborigines, not trepangers and the trepang industry. The ethnographic approach to the history and heritage of Australia's early trepang industry persists to this day, but to some extent it has been broadened by efforts to understand the background from which the trepangers came.

Given the greater measure of scholarly attention directed to the trepangers in recent times, it is perhaps unsurprising that Macknight lodges a belated admonition on 'the wild use of the unfortunate term "Macassan"'. Although Macknight's chapter does not elaborate on the matter, we think it is important to briefly consider this point. Viewed from the perspective of the trepangers themselves, the term 'Macassan' would seem to be very odd indeed. No-one from Makassar, either in the current era or in centuries past, would identify themselves as a 'Macassan'. As Macknight (2011, p. 129) observes, 'the term "Macassan" (or "Makassan") has no currency in an Indonesian context'. Nonetheless, most of the trepangers voyaging to Australia's north regarded Makassar as their home port, and because the trade in trepang was centred in Makassar, for better or worse, scholars, including Macknight in his earlier publications, have embraced the term. Yet, as mentioned earlier, these fishers were of diverse ethnicity. Besides the ethnic Makassarese who are predominantly located on the western coast of the South Sulawesi peninsula, the most prominent Sulawesi-based populations involved in trepang gathering were the Bugis (or Buginese), the Butonese and the Bajau. Nonetheless, the 'Macassan' term has firmly lodged itself in the popular consciousness, including the next generation of scholars writing on the impact of the trepang industry, many of whom are archaeologists working on trepanging sites, albeit with an ethnographic bent. With acute insight, Macknight examines a number of the key archaeological puzzles, including the perennial question: when did the trepangers first set foot on Australian soil? Asking such a question is a good indication of the focus of the more recent scholarly trends in the literature on trepang, including a greater focus on the biological and economic aspects of trepang and, as mentioned, a newfound fascination with the trepangers themselves.

Although Reid's chapter diverges somewhat from a direct focus on the so-called 'trepang trail', to some extent his chapter is a manifestation of what Macknight acknowledges is the dominant trend in the current literature on the trepang industry. That is, an examination of the Macassan trepang industry in terms of the broader picture, including the world of the trepangers, who were among the first seafarers to brave the Arafura Sea, which, because it straddles the deep troughs between the Sunda and Sahul tectonic plates, 'has formed the world's greatest divide throughout human history'. Reid argues that the 'Great Divide' of the Arafura has ensured that the world of Makassar has been largely separated from the world of Marege', even in the modern era. Despite early trading links, the overarching narrative of Australia's relations with its northern neighbours 
has been one of mutual incomprehension. It didn't have to be this way. For instance, as Reid describes, Australia's military and diplomatic engagement with the region, particularly in the World War II period, was followed in the postwar era by Australia playing a potentially decisive role in the postwar Asian order. This was particularly so in the case of Indonesia, which was determined to shrug off its colonial shackles. Australian unions, which refused to facilitate the postwar return of the Dutch colonial masters, played a key role in Indonesia's assertion of independence. These initial tentative forays into the region, however, were preceded and to some extent overshadowed by the Immigration Restriction Act, which dates, in Commonwealth legislation, from 1901. This led to the flagrantly xenophobic White Australia Policy and a subsequent disavowal of the early history and heritage of the trepangers and others like them, such as the Aboriginal and then Indonesian, Filipino and Japanese divers of pearl and pearl shell. It should be a source of great shame that Australia's collective ambivalence, if not outright hostility, towards its historical links with Asialinks that were bravely forged in the face of the deep geographic divide of the Arafura Sea-persists.

The chapters by Ganter and Thomas nuance the notion that Australia is somehow threatened by or evasive of its history of Asian engagement. Although both authors recognise the fact that certain Asia-related histories have, in Ganter's words, 'sailed below the wind of popular attention', both of these chapters demonstrate how Australians have, on occasion, successfully understood and responded to Asia. Ganter's chapter, for instance, examines the link between the arrival of the Macassan trepangers and the early history of Islam in Australia. In particular, Ganter highlights the engagement of Indigenous people with their 'mixed histories' in relation to Asians, Pacific Islanders and Muslims, the last of which includes 'Afghan' cameleers, 'Malay' pearl divers and 'Macassan' trepangers. In one sense this chapter echoes Reid's broader consideration of other, less well-documented aspects of the contact between northern Australia and its neighbours on the other side of the Arafura. Just as others have attempted to 'write' the Afghan cameleers back into Australian history, Ganter aims to 'write back in' the groundbreaking role of the Macassan trepangers in bringing Islamic influence to the Yolngu and neighbouring Aboriginal communities of Arnhem Land. Thomas's chapter also aims to reinsert several forgotten figures into Australia's early history-namely, three interpreters of Indonesian background who assumed the roles of intermediaries between the early European pioneers and the Indonesian trepangers. After discovering the trepang industry in 1803, the European pioneers were keen to understand as much as they could about it in order to incorporate it into the colonial trading network. To do this effectively, they needed the services of interpreters and translators. The three figures Thomas examines - namely, Abraham Williams, Oodeen and Tingha de Hans - were exemplary in this regard. Thomas's chapter 
demonstrates that like so many of the actors involved in the Macassan era, these three men, although subject to their conditions of engagement, were free agents, disinclined to serve their colonial employers in a subservient way. By emphasising the fact that these men are, above all, interpreters, Thomas demonstrates how they have played a crucial role in ensuring that the voice of the various Indonesian fishers and traders working along Australia's northern coast was heard, understood and recorded for posterity. Reflecting on their unique skills, in the case of Oodeen and Tingha, for example, Thomas asserts that they were clearly intelligent and determined individuals, characteristics that need to be considered when assessing them as adaptable linguists, capable of going beyond their own language and culture'.

The chapters by McIntosh and Bilous squarely focus on the impact of the Macassans on the Indigenous communities of northern Australia. In a chapter finetuning his previous research on the pre-Macassans mentioned earlier, McIntosh shares a pre-Macassan story told to him by David Burrumarra, a Yolngu elder. He draws some conclusions on why the story was shared, shining light on what 'coming home' means in terms of contemporary relations between Yolngu and outsiders such as the Macassans and pre-Macassans. The aim of this chapter is to show how some Yolngu view the history and legacy of trepanging not just through the narrow lens of tamarind trees, pottery shards and the years 1780-1907, but, rather, through an entirely different and sacred lens. The chapter by Bilous takes a more analytical approach to analysing general public engagement with Macassan heritage in Australia. Through an analysis of Walkabout, National Geographic and Australian Geographic articles from the 1930s to the present, Bilous questions the ways in which stories of MacassanIndigenous Australian connection are represented to a non-academic, popular audience. The links between political discourses of the time and these popular magazine articles are clearly drawn, including attitudes to landownership and terra nullius and the idea of Arnhem Land as a 'frontier' landscape. Perhaps most intriguing in her findings is the persistence, despite significant evidence to the contrary, that Indigenous Australians were an unchanging people - across time and place. As Bilous states,

The representation of Macassan and Indigenous Australian contact stories - where Indigenous Australians were an integral part of an informal international trade network-would presumably disrupt some of these discourses. Instead, these same discourses are used to tell contact stories in a way that strengthens and reinforces the stereotypes and geographical marginalisation of Arnhem Land and the people who live there.

The next chapter in this volume, by Taçon and May, presents findings from new archaeological research taking place in northern Australia and relating to 
Macassan-Indigenous Australian contact. It focuses on the search for evidence of Macassan contact in rock art from northwestern Arnhem Land. As Taçon and May state, 'Contact rock art provides us with some of the only contemporary Indigenous accounts of interactions that were taking place over hundreds of years. In this regard, it is a unique archive of Australian history, providing insight into the relationships formed between local Aboriginal groups and visitors.' This chapter presents specific information on new sites documented as part of an Australia-wide contact-period rock art study and evaluates previously published statements on 'Macassan' rock art in Australia.

The next two chapters turn an anthropological gaze on Macassan contact and material culture. Brady, for instance, explores the introduction of drug substances to Australia by the Macassans. She argues for a re-examination of our longstanding assumptions relating to the introduction and adoption of new drugs in Australia as well as the processes and adaptations to material culture used to consume such substances. As Brady observes in her chapter, it has been universally assumed that the Macassans were the ones who introduced the smoking of tobacco to coastal Aboriginal peoples using long 'Macassan' pipes. Strangely though, according to Brady, there is little evidence that the Macassans themselves ever used the pipes in this way for tobacco alone. As well as tobacco, Brady explores the use and spread of arrack (a spirit often made from the fermented sugars and sap of particular plants and trees) and betel nut (the nut or seed of the areca palm chewed together with the leaf of the betel pepper and lime with tobacco added as flavouring).

The chapters by Clark and Adhuri shift the focus of this volume away from Marege' to squarely address the historical legacy of the Macassan trepang industry in contemporary Indonesia and its environs. In these two chapters there is a particular focus on the 'living history' epitomised by Makassar's rich maritime heritage and the contemporary trepang fisheries of South Sulawesi and the Australian MoU Box (an area of Australian water in the Timor Sea where Indonesian traditional fishers, using traditional fishing methods only, are permitted to operate). Clark's chapter initially examines what could be understood as examples of tangible 'Macassan heritage' in contemporary Makassar: authentic monuments, historical objects and sites with distinctive connections to the fishers and entrepreneurs involved in the Macassan trepang industry. Unfortunately, it soon becomes evident that there is very little remaining in the way of tangible Macassan heritage, either in Makassar itself or in South Sulawesi in general. But this should not mean that there is no Macassan heritage in Sulawesi-far from it. This is especially the case if the Macassan heritage of South Sulawesi is understood as an ongoing cultural process with associated intangible values. Similarly, Adhuri's chapter examines the contemporary trepang fisheries along the border area of the Indonesian and Australian fishing 
zones as a site of continuous and ongoing history, with close historical links to the Macassans. Adhuri achieves this by comparing the characteristics of a so-called 'traditional' trepang fishery (practised by the Oelaba trepang fishers of Rote Island) with a contemporary or supposedly 'non-traditional' trepang fishery (practised by the Oesapa trepang fishers, also of Rote), both of which are based in the MoU Box region. Ironically, Adhuri's chapter suggests that the relative newcomers to the trepang industry, the so-called 'non-traditional' Oesapa fishers, many of whom can directly trace their ethnic heritage to the various ethnic groups of South Sulawesi, are closely connected to the Macassan pioneers of centuries past.

The final chapter of this volume, by Blair and Hall, raises the possibility of seeking greater global recognition for the heritage of the Macassan trepang foodway. They consider its potential to be recognised as a cultural route of outstanding universal value under the UNESCO World Heritage Convention. This chapter's underlying argument is innovative, timely and important. In 1992 the World Heritage Convention became the first international legal instrument to recognise and protect cultural landscapes of outstanding universal value. In 2005, the concept was widened to include cultural routes and itineraries, and an international scientific committee has been established to promote research and World Heritage inscriptions in this area. The new cultural routes category highlights long-distance routes and journeys, such as those associated with trade or pilgrimage, which have linked people, countries, regions or even continents for long periods. Little work has been done to date on the recognition of maritime trading routes on a regional or global scale or on communicating their values as universal cultural heritage. In many respects the Macassan trepang pathway - extending from southern China in the north and the Kimberley and Arnhem Land in the south - is a worthy contender for the world's first UNESCO-listed maritime cultural route. Much more work will need to be done to ensure such a nomination sees the light of day, potentially involving complex exchanges and collaborations between local groups as well as numerous national and international entities. This collection is but one small step in this process.

\section{References}

Australian Fisheries Management Authority (AFMA) (2006) Annual Report 2005-2006, Canberra: Australian Fisheries Management Authority.

Australian Fisheries Management Authority (AFMA) (2007) Annual Report 2006-2007, Canberra: Australian Fisheries Management Authority. 
Department of Sustainability, Environment, Water, Population and Communities (2011) Assessment of the Northern Territory Trepang Fishery, Canberra: Department of Sustainability, Environment, Water, Population and Communities.

Chaloupka, G. (1993) Journey in Time: The 50,000 year story of the Australian Aboriginal art of Arnhem Land, Chatswood, NSW: Reid.

Chaloupka, G. (1996) 'Praus in Marege: Makassan subjects in Aboriginal rock art of Arnhem Land, Northern Territory, Australia', Anthropologie, 34 (1-2), pp. 131-42.

Choo, P. (2008) 'Population status, fisheries and trade of sea cucumbers in Asia', in V. Toral-Granda, A. Lovotelli and M. Vasconcellos (eds), Sea Cucumbers: A global review of fisheries and trade, Rome: Food and Agriculture Organization of the United Nations, pp. 81-110.

Clarke, A. (1994) Winds of change: an archaeology of contact in the Groote Eylandt archipelago, Northern Australia, Unpublished PhD thesis, The Australian National University, Canberra.

Clarke, A. (2000) 'The "Moorman's trousers": Macassan and Aboriginal interactions and the changing fabric of Indigenous social life', in S. O'Connor and P. Veth (eds), East of Wallace's Line: Studies of past and present maritime societies in the Indo-Pacific region, Modern Quaternary Research in Southeast Asia 16, Rotterdam: A. A. Balkema, pp. 315-35.

Clarke, A. and U. Frederick (2006) 'Closing the distance: interpreting crosscultural engagements through Indigenous rock art', in I. Lilley (ed.), Archaeology in Oceania, Australia and the Pacific Islands, Malden, Mass.: Blackwell, pp. 116-33.

Clarke, A. and U. Frederick (2011) 'Making a sea change: rock art, archaeology and the enduring legacy of Frederick McCarthy's research on Groote Eylandt', in M. Thomas and M. Neale (eds), Exploring the Legacy of the 1948 Arnhem Land Expedition, Canberra: ANU E Press, pp. 135-55.

Cleary, P. (2010) 'Local fishers to opt out to foreign boats', The Australian, 27 December, <http://www.theaustralian.com.au/news/nation/local-fishingfleet-to-opt-out-to-foreign-boats/story-e6frg6nf-1225976467846>

Commonwealth Fisheries Association (2012) New maritime laws to increase fishing industry labour shortages, Media release, 16 March, Deakin, ACT: Commonwealth Fisheries Association, <http://comfish.com.au/wp-content/ uploads/2012/03/CFA-Media-Release-New-maritime-laws-to-increasefishing-industry-labour-shortages-16-March-2012.pdf $>$ 
Fox, J. J. (1977) 'Notes on the southern voyages and settlements of the SamaBajau', Bijdragen Tot de Taal-, Land-en Volkenkunde (BKI), 133, pp. 459-65.

Fox, J. J. and S. Sen (2002) A study of socio-economic issues facing traditional Indonesian fishers who access the MoU box, Canberra: Department of Sustainability, Environment, Water, Population and Communities.

Francis, A. (2005) 'Expanding the Territory's oldest export business', ABC Rural: Northern Territory, 30 May, <http://www.abc.net.au/rural/nt/stories/ s1380107.htm>

Francis, A. (2006) 'Trepang poachers fined in Kimberley', ABC Rural: Northern Territory, 5 June, <http://www.abc.net.au/rural/nt/content/2006/s1655553. htm >

Ganter, R. (2006) Mixed-Relations: Asian-Aboriginal contact in north Australia, Crawley, WA: University of Western Australia Press.

Gibson, J. and I. Razak (2011) 'Illegal fishing captures fall in Top End waters', $A B C$ News, 29 April, <http://www.abc.net.au/news/2011-04-29/illegalfishing-captures-fall-in-top-end-waters/2701078>

Howlett, C. (2011) 'Fishing without borders', ABC Environment, 13 December, <http://www.abc.net.au/environment/articles/2011/12/13/3389001.htm>

Knapp, G. and H. Sutherland (2004) Monsoon Traders: Ships, skippers and commodities in the eighteenth century, Leiden: KITLV Press.

Lloyd, G. (2012) 'Cast out', The Weekend Australian Magazine, 17-18 March, pp. 15-18.

McIntosh, I. (1995) 'Who are the Bayini?' The Beagle: Records of the Museums and Art Galleries of the Northern Territory, 12, pp. 193-208.

McIntosh, I. (2011) 'Missing the revolution! Negotiating disclosure on the preMacassans (Bayini) in north-east Arnhem Land', in M. Thomas and M. Neale (eds), Exploring the Legacy of the 1948 Arnhem Land Expedition, Canberra: ANU E Press.

Macknight, C. C. (1972) 'Macassans and Aborigines', Oceania, 42, pp. 283-321.

Macknight, C. C. (1976) Voyage to Marege': Macassan trepangers in northern Australia, Carlton, Vic.: Melbourne University Press.

Macknight, C. C. (1986) 'Macassans and the Aboriginal past', Archaeology in Oceania, 21 (1), pp. 69-75. 
Macknight, C. C. (2008) 'Harvesting the memory: open beaches in Makassar and Arnhem Land', in P. Veth, P. Sutton and M. Neale (eds), Strangers on the Shore: Early coastal contacts in Australia, Canberra: National Museum of Australia, pp. 133-47.

Macknight, C. C. (2011) 'The view from Marege': Australian knowledge of Makassar and the impact of the Trepang industry across two centuries', Aboriginal History, 35, pp. 121-43.

Marika, B. (2008) 'Foreword', in M. West (ed.), Yalangbara: Art of the Djang'kawu, Darwin: Charles Darwin University Press, pp. 8-9.

Mitchell, S. (1994) Culture contact and Indigenous economies on the Cobourg Peninsula, northwestern Arnhem Land, Unpublished PhD thesis, Northern Territory University, Darwin.

Mitchell, S. (1997) 'George Sunter, trepanger', in G. H. Sunter (ed.), Adventures of a Trepang Fisher, Carlisle, WA: Hesperian Press, pp. i-iii.

Morphy, H. (2008) 'Yalangbara: the paintings', in M. West (ed.), Yalangbara: Art of the Djang'kuwu, Darwin: Charles Darwin University Press, pp. 65-76.

Stacey, N. (2007) Boats to burn: Bajo fishing activity in the Australian fishing zone, Canberra: ANU E Press.

Sutherland, H. (2000) 'Trepang and wangkang: the China trade of eighteenthcentury Makassar c. 1720s-1840s', Bijdragen tot de Taal-, Land- en Volkenkunde (BKI), 156, pp. 451-72.

Taçon, P. S. C, S. K. May, S. J. Fallon, M. Travers, D. Wesley and R. Lamilami (2010) 'A minimum age for early depictions of Macassan praus in the rock art of Arnhem Land, Northern Territory', Australian Archaeology, 71, pp. 1-10.

Theden-Ringl, F., J. Fenner, D. Wesley and R. Lamilami (2011) 'Buried on foreign shores: isotope analysis of the origin of human remains recovered from a Macassan site in Arnhem Land', Australian Archaeology, 73, pp. 41-8. 